\title{
The Phytochemistry and The Anti-Bacterial Activity of Yellow Root (Arcangelisia flava Merr.) against
}

\section{Aeromonas hydrophila}

\author{
Maryani \\ Doctoral Degree, Faculty of Fisheries and Marine Science \\ Brawijaya University-Malang, 65145, Indonesian \\ Marsoedi \\ Faculty of Fisheries and Marine Science \\ Brawijaya University-Malang, 65145, Indonesian
}

Happy Nursyam

Faculty of Fisheries and Marine Science

Brawijaya University-Malang, 65145, Indonesian

Maftuch

Faculty of Fisheries and Marine Science

Brawijaya University-Malang, 65145, Indonesian Fax: 62-34-1557837

Tel: 62-34-155-3512_E-mail: faperik@ brawijaya.ac.id

Received: February 24, 2013 Accepted: March 9, 2013

doi:10.5296/jbls.v4i2.3683 URL: http://dx.doi.org/10.5296/jbls.v4i2.3683

\begin{abstract}
Arcangelisia flava Merr had been long recognized by the Dayak community at Central Kalimantan. It was used for natural herbal due to its capability to medicate various diseases.
\end{abstract}




\section{Al Macrothink}

Journal of Biology and Life Science ISSN 2157-6076 2013, Vol. 4, No. 2

It seemed that this plant was considered as having active substances that was useful for health. Therefore, $f$ urther review on phytochemical components should be needed through screening and identifying the bioactive substance, and implementing a specific review about the solvent that was producing extract with high level of rendement and preventive zone. Result of the extraction of Yellow Root (Arcangelisia flava Merr) showed that the rendement rate of methanol solvent was the highest. The phytochemical screening of the extract result was aimed to ensure the presence of alkaloid, flavonoid, saponin, triterpen and tannin. Result of the test indicated that Yellow Root (Arcangelisia flava Merr.) contained of alkaloid, flavonoid, saponin and terpenoid compounds, while tannin was not detected. The use of chloroform solvent was producing the extract result with widest preventive zone $(17.25 \mathrm{~mm})$ on $A$. hydrophila.

Keywords: Anti-Bacterial, Phytochemical, Arcangelisia flava Merr, Aeromonas hydrophila

\section{Introduction}

Indonesia was known for its natural biodiversity. Some of natural plants had been long used for traditional herbals. It was indeed that traditional herbals were one cultural legacy that should be preserved. The quality of traditional herbals might need to be improved through the use of advanced knowledge and technology in order to use them as the alternative agent to "modern drug" because its efficacy had been medically verified (Yulita, 2002).

Central Kalimantan had the biggest jungle with various herbal plants. The community had used such plants for their self-need or taken benefit from commercializing these plants. For preservation issue, these herbals should be conserved ex situ. Some herbals that were potentially being used for the raw material of potion would be further researched. Plants with efficacy of being used for medicine were also examined. The added value for these herbals could be identified through research on chemical substance and its efficacy. Therefore, research on the phytochemistry and its anti-bacterial activity test of these herbals was absolutely needed. This research was aimed to understand the phytochemical components of the herbals through methods of screening and identifying the bioactive substance, and implementing a specific review about the solvent that was producing extract with high level of rendement and preventability. It was then found that Yellow Root (Arcangelisia flava Merr) had antibacterial capability against Aeromonas hydrophila.

\section{Material and Method}

Yellow Root (Arcangelisia flava Merr) was obtained from Central Kalimantan forest. Extraction and phytochemical test were conducted at Integrated Research and Testing Laboratory of University of Gajah Mada (LPPT-UGM) Yogyakarta. Anti-bacterial activity test was carried out at Microbiology Laboratory of Faculty of Medicine, University of Brawijaya.

\section{Research Method}

\subsection{Extraction of Yellow Root (Arcangelisia flava Merr)}

Extraction method was one that had been used by Darusman et al., 1995). Yellow Root powder was macerated in the methanol, ethanol, acetone, ethyl acetate, n-hexane and chloroform 
solvents of the pro-analysis (p.a) grade. The results were incubated for 24 hours. The filtrate was then screened and thickened with vacuum rotary evaporator at $37^{\circ} \mathrm{C}$ until the thick extract was obtained. It was screened for several times to produce the final solvent without color. Result of rendement was then counted.

\subsection{The Testing of Phytochemical Active Substance of Yellow Root (Arcangelisia flava Merr)}

Bioactive compounds in the Yellow Root were acknowledged through phytochemical test. The result included phenolic, tannin, steroid, saponin, flavonoid and alkaloid. The analysis procedure of bioactive compounds was using method of Sangi et al., 2008). This method was explained as following:

Alkaloid Test. Yellow Root sample was refined and prepared for 4 grams. It was then mixed with $10 \mathrm{ml}$ ammonia and $10 \mathrm{ml}$ chloroform. The solvent was screened into the reaction tube. Ten drops $\mathrm{H} 2 \mathrm{SO} 42 \mathrm{~N}$ were included into filtrate. This mixture was regularly shaken. Upper layer was then removed into three reaction tubes, with each for $1 \mathrm{ml}$. After this, each tube was given few drops of Mayer reactant, Wagner reactant, and Dragendorff reactant. The presence of precipitation meant that the sample contained alkaloid. Mayer reactant produced white precipitation. Wagner reactant was resulting in brown precipitation, while Dragendorff reactant was giving orange-red precipitation.

Flavonoid Test. Yellow Root sample was refined and weighted for 200 grams. It was then extracted with $5 \mathrm{ml}$ ethanol and heated for 5 minutes in the reaction tube. Few drops thick $\mathrm{HCl}$ were added. After this, $0.2 \mathrm{~g} \mathrm{Mg}$ powder was added. The result was positive if dark red color was presented for 3 minutes.

Saponin Test. Yellow Root sample was refined and prepared for 2 grams. It was then entered into reaction tube, added by aquades to soak all proportions of sample, boiled for 2-3 minutes, cooled, and strongly shaken. The positive result was shown by the presence of stable foam.

Terpenoid Test. Yellow Root sample was refined and weighted for 50-100 mg. Glacial acetate acid was added to soak the sample. It was incubated for 15 minutes. Six drops of the mixture were removed into reaction tube, and 2-3 drops of thick sulfate acid were added into the tube. The presence of terpenoid was indicated by red, orange-red or purple colors.

Tannin Test. Yellow Root sample was refined and prepared for $20 \mathrm{mg}$. Ethanol was added to soak the sample. Then, 2 to 3 drops $1 \% \mathrm{FeCl} 3$ were added. The positive result was ensured by the presence of bluish black or green colors.

\subsection{Anti-Bacterial Test of against A. hydrophila Extract with Disc Method with Different Solvents}

Pure culture of A. hydrophila bacteria was obtained from Balai Besar Pengembangan Budidaya Air Payau (BBPBAP) Jepara and then, bacteria were rejuvenated at Microbiology Laboratory, Faculty of Medicine, University of Brawijaya. Before used for anti-bacterial test, the bacteria were rejuvenated because bacteria that were used for antibacterial test were those with age of 24 hours. The procedures to rejuvenate bacterial culture were: 
- $\quad \mathrm{NB}$ solution was prepared for $5 \mathrm{ml}$ in the reaction tube.

- $\quad$ Pure culture of A. hydrophila bacteria was taken aseptically for one ose, and then, put into NB media.

- $\quad$ The bacterial-containing NB solution was incubated for 24 hours at $37^{\circ} \mathrm{C}$.

- After 24 hours storage, the bacteria in the NB media were cultured again in the solid media, which was TSA media, and re -incubated for \pm 24 hours.

- After 24 hours, the bacteria were ready to use for anti-bacterial test.

This antibacterial test was based on Brock and Madigan's method (1991). It was used to figure out the most effective solvent to become the anti-bacterial material to be used in the disc method (Hadioetomo, 1983). Anti-microbial capacity was examined by measuring the diameter of preventive zone around disc paper that was given by Arcangelisia flava Merr extract. There were stages in the disc test, such as:

- Petri dish was prepared and sterilized.

- Agar media were prepared and poured evenly onto the surface of Petri dish.

- The media was waited until cold.

- Two drops of bacteria were given evenly to the surface of Petri dish by using triangle.

- After 15 - 30 minutes, disc paper that contained Yellow Root extract was put into the media and pressed such that Yellow Root extract was absorbed well.

- The examination of result was done after media were incubated at $35^{\circ} \mathrm{C}$ for $18-24$ hours by measuring the diameter of preventive zone around disc paper using millimeter paper or ruler, and then recording it.

Data that were collected were analyzed descriptively to determine the best solvent to prevent bacterial growth.

\section{Result}

\subsection{Result of Extraction of Yellow Root (Arcangelisia flava Merr)}

Result of extraction of Arcangelisia flava Merr. was shown in Table 1. The extracts of Yellow Root (Arcangelisia flava Merr.) were different based on the solvent type such as chloroform extract, n-hexane extract, ethyl acetate extract, methanol extract, ethanol extract, and acetone extract. Rendement was representing a comparison between extract weight and initial weight of the material, and this was measured by percentage (\%).

Table 1. The result of extraction of Yellow Root (Arcangelisia flava Merr.)

\begin{tabular}{|l|l|l|l|}
\hline Type of Solvent & Sample Weight gram) & Heavy crude extract (gram) & $\%$ yield (w/w) \\
\hline Kloroform & 50 & 0.09 & 0.17 \\
N-heksan & 50 & 0.07 & 0.14 \\
Etil Asetat & 50 & 1.44 & 2.87 \\
\hline
\end{tabular}




\begin{tabular}{|l|l|l|l|}
\hline Metanol & 50 & 2.87 & 5.73 \\
Etanol & 50 & 2.45 & 4.91 \\
Aceton & 50 & 1.76 & 3.53 \\
\hline
\end{tabular}

Result of Phytochemical Test

Phytochemical test against Yellow Root (Arcangelisia flava Merr.) with methanol solvent might produce the highest rendement rate. Based on the result of phytochemical test, there were secondary metabolite compounds that were contained within Yellow Root (Arcangelisia flava Merr.). It was shown in Table 2.

Table 2. The Result of Phytochemical Test of Yellow Root (Arcangelisia flava Merr.)

\begin{tabular}{|l|l|c|}
\hline & \multicolumn{1}{|c|}{ Testing methods } & Result \\
\hline Alkaloid & Pereaksi Mayer & +++ \\
& Perekasi Wagner & ++ \\
& Pereaksi Dragendorff & ++ \\
Flavonoid & Etanol & +++ \\
Saponin & Aquades & + \\
Terpenoid & Uji & ++ \\
& Liebermann-Bucchard & \\
& & \\
Tanin & $\mathrm{FeCl}_{3}$ & - \\
\hline
\end{tabular}

( - ) Not detected

$(+) \quad$ The intensity of the weak

$(++)$ Strong intensity

$(+++)$ The intensity is very strong

\subsection{Antibacterial Activity Test of the Compounds}

Testing anti-bacterial activity was by ensuring whether anti-bacterial activity of Yellow Root (A. flava Merr.) was existed or not. A method in the anti-bacterial test was disc diffusion (agar diffusion method) with poured agar. According to Kim (1995), the extract was considered as active if it could prevent the growth of bacterial at concentration of $20 \square \mathrm{g} / \mathrm{ml}$. The preventive zone of Yellow Root (A. flava Merr.) extract against the tested bacteria Aeromonas hydrophila was shown in Figure 1 and Table .

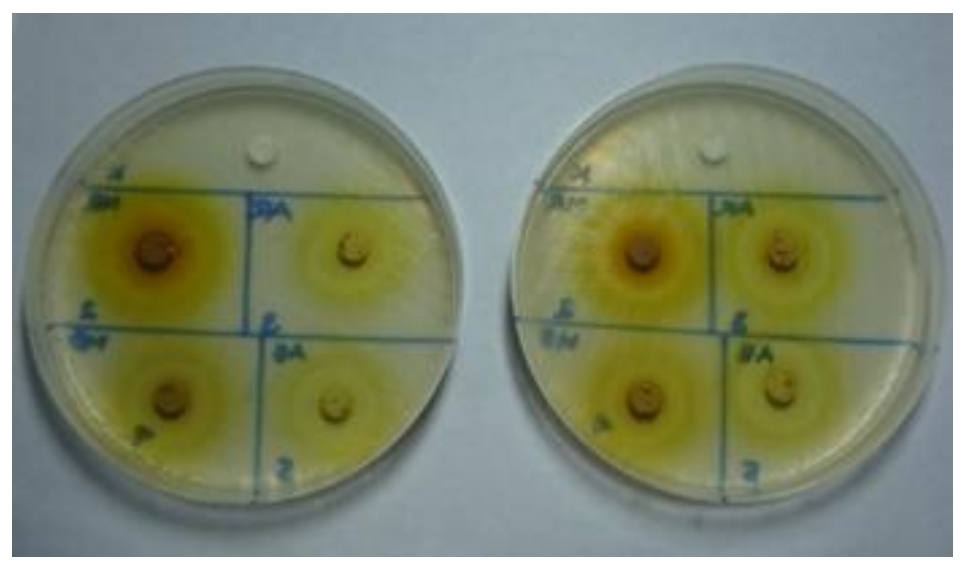

Figure 1. Inhibition zone of Yellow Root (A. flava Merr.) 
Table 3. The diameter of Inhibition zone of Yellow Root (A. flava Merr.)

\begin{tabular}{|c|l|c|l|}
\hline \multicolumn{2}{|l|}{ Particulars: } \\
\hline & Petri disc 1 & & Petri disc 2 \\
\hline 1. & Etil Asetat & 5. & N- Heksan \\
\hline 2. & Metanol & 6. & Kloroform \\
\hline 3. & Etanol & 7. & Water \\
\hline 4. & Aceton & 8. & Dietil Eter \\
\hline & Kloroform solvent (control - ) & & Etanol solvent (control - ) \\
\hline
\end{tabular}

Table 3. The diameter of Inhibition zone of Yellow Root (A. flava Merr.)

\begin{tabular}{|l|c|}
\hline \multicolumn{1}{|c|}{ Extract } & Inhibition Zone $(\mathrm{mm})($ Mean \pm SD) \\
\hline Kloroform & $17.25 \pm 0.65$ \\
\hline N-heksan & $13.18 \pm 0.37$ \\
\hline Etil Asetat & $11.16 \pm 0.75$ \\
\hline Dietil Eter & $10.07 \pm 0.24$ \\
\hline Metanol & $9.51 \pm 0.22$ \\
\hline Etanol & $9.01 \pm 0.29$ \\
\hline Aceton & $10.07 \pm 0.52$ \\
\hline Water & $8.46 \pm 0.33$ \\
\hline $\begin{array}{l}\text { Control negative } \\
\text { Kloroform solvent } \\
\text { Etanol solvent }\end{array}$ & - \\
\hline
\end{tabular}

\section{Discussion}

The highest extract weight was developed from Arcangelisia flava Merr. that was extracted by methanol solvent (polar solvent). It is then understood that Yellow Root (Arcangelisia flava Merr.) contained polar substances and it was less surprised if the greatest quantity of rendement was that obtained from methanol solvent. It was consistent to the proposition that methanol was able to extract organic compound, some lipids and tannin, and therefore, the result of methanol extraction was very great (Karaman et al., 2003; Parekh et al., 2007). The result of extraction was affected by some factors such as natural material, extraction method, sample particle size, and the condition and length of sample storage (Igbinosa et al., 2009; Barbour et al., 2004; Sokmen et al., 2004; Gulluce et al., 2003).

The extract that was obtained from the extraction process of Yellow Root (Arcangelisia flava Merr.) was in the form of pasta. The color was different but still visually seen. Extraction with chloroform and n-hexane solvents produced yellow-colored extract, while extraction with ethyl acetate solvent produced dark yellow-colored extract. Meanwhile, extraction with methanol, ethanol and acetone solvents was resulting in thick yellow-colored extract.

Yellow color in these three extractions was caused by active berberina substance that was indeed yellow coloring agent (Henry, 1913). Review of literature showed that solvents in the extraction would destroy cellular membrane and dissolve pigments (Shidduraju and Becker, 2003; Ra et al., 1998; Kahkonen et al., 1999). Non-polar solvent, such as chloroform, was 
effective to dissolve alkaloid in the alkali form (Jaiarj et al., 1999; Sosa et al., 2010). Semi-polar solvent, such as ethyl acetate, was able to extract phenol and terpenoid compounds, while polar solvent, like methanol, was able to extract quarterner alkaloid compound, phenolic component, carotenoid and tannin (Harborne, 1987,).

According to the result of phytochemical test, it was recognized that Yellow Root (A. flava Merr.) contained alkaloid, flavonoid, saponin, and terpenoid compounds but tannin was not detected. The presence of alkaloid was acknowledged through the precipitation. Mayer reactant reacted with alkaloid to produce white precipitation. Wagner reactant reacted with alkaloid and produced brown precipitation. The reaction of Dragendorff reactant with alkaloid resulted in orange-red precipitation (Robinson, 1995). The presence of flavonoid was ensured through red color due to the existence of flavilium salt (Achmad, 1986).

Yellow Root (A. flava Merr.) also contained saponin compound. It is confirmed through the production of stable foam. According to Robinson (1995), polar and non-polar compounds were active on the surface such that if these are shaken with water, saponin would produce micelle. In the micelle structure, polar cluster faced outward, while non-polar cluster faced inward. Both conditions were similar to foam. Terpenoid content was tested using Liebermann-Bucchard Method, and the presence was confirmed with orange-red or purple colors (Harborne, 1987). Terpenoid compound was able to produce orange-red color after being reacted with thick $\mathrm{H} 2 \mathrm{SO} 4$ in the glacial acetate solvent. Based on the result of phytochemical test, it was reported that Yellow Root (A. flava Merr.) was indeed containing terpenoid compound. The presence of this compound was indicated by discoloration into orange-red and purple after thick $\mathrm{H} 2 \mathrm{SO} 4$ was added.

Result of examination of tannin compound indicated that Yellow Root (A. flava Merr.) did not contain tannin compound because the detection by adding $1 \% \mathrm{FeCl} 3$ did not produce blackish green color. The addition of $1 \% \mathrm{FeCl} 3$ would ensure the reaction of this additive with a hydroxyl cluster in the tannin compound. It seemed that $\mathrm{FeCl} 3$ reactant had been widely used to identify phenol compound, including tannin (Robinson, 1995).

Chloroform, n-hexane, ethyl acetate, methanol, ethanol, acetone extracts, and one extract using water from Arcangelisia flava Merr. plant, were able to prevent bacteria Aeromonas hydrophila. Preventive zone that was produced by methanol, ethanol, and plant-based water extract was classified in the medium category width between 5 and $10 \mathrm{~mm}$. It was consistent to preventive zone category for anti-bacterial as reported by Toma and Barriault (1995) who proposed that the preventive zone width of 5-10 mm was in the medium category. Preventive zone with the width less than $5 \mathrm{~mm}$ was in the weak category. The width of preventive zone that was produced by Arcangelisia flava Merr. extract was influenced by organism sensitivity, culture medium, incubation condition, and agar diffusion speed. It supported the findings in previous researches about factors influencing agar diffusion speed, which were microorganism concentration, media composition, incubation temperature, and incubation length (Schlegel et al, 1994; Ponnusamy et al., 2010).

Chloroform, n-hexane, ethyl acetate, and acetone extracts provided the wider preventive zone than methanol, ethanol and water extracts. Preventive zone that was produced by chloroform, 
n-hexane, ethyl acetate, and acetone extracts from Arcangelisia flava Merr. was included in the strong category because the width was more than $10 \mathrm{~mm}$, that preventive zone width of more than $10 \mathrm{~mm}$ was considered as strong preventive zone category. Chloroform, n-hexane, ethyl acetate and acetone extracts from Arcangelisia flava Merr. had different preventive zone because it was influenced by different active substance that was contained in each extract.

Antibacterial ctivity test was aimed to figure out the ability of Yellow Root (A. flava Merr.) in controlling microorganism. This microorganism was a microscopic-size organism that could only be seen in the high level of magnificence power. One kind of microorganism was bacteria. Indeed, bacteria were a distinctive unicellular prokaryotic cell. Some bacterial species might cause disease (pathogen) against human, animal and plant, or contaminate foods and destroy material substance (Toranzo et al., 1983; Pelczar and Chan, 1986). Therefore, good control actions for bacterial growth were needed, involving either physical or chemical measures. A measure that was used to control bacteria was anti-bacterial. It was then admitted that anti-bacterial was a compound that was able to prevent the growth of bacteria or even to kill bacteria.

A factor causing different preventive zone with was the effect of compound content in each extract. Active compound diffused with agar and produced the concentrated gradient. The highest concentration was found in the area nearby paper disc, and it is decreased with the further distance from paper disc (Parish and Davidson, 1989). Speed and efficiency of microbial destruction by anti-microbial compounds were influenced by temperature, $\mathrm{pH}$, timing, concentration, and the presence of other organic component (Ringo et al., 2004; Zong et al., 2002). The presence of organic component was a factor influencing speed and efficiency of microbial destruction by anti-microbial compound. It was consistent to a finding that organic compound might reduce anti-microbial activity by inactivating and disturbing the contact between anti-microbial substance and microbial cell, thus protecting microbial from the effect of anti-microbial substance (Fardiaz et al., 1988). Negative control was the solvent of each extract. At chloroform extract, the negative control was chloroform solvent. The negative control of $n$-hexane extract was n-hexane solvent. The negative control of ethyl acetate, methanol, ethanol and acetone extracts was then also ethyl acetate, methanol, and ethanol as well as acetone solvents. The negative control did not have preventive zone and it was ascertained by the absence of transparent zone around paper disc. The absence of preventive zone proved that the extract might have anti-bacterial activity not because of the effect of solvent, but because it was genuinely cultured from the active substance of A. flava Merr.

\section{Conclusion}

Considering results and discussions above, it was concluded that:

1. The biggest rendement from the extraction of Arcangelisia flava Merr. was rendement that was using methanol solvent, with the rate of $5.73 \%(\mathrm{w} / \mathrm{w})$.

2. Result of phytochemical test indicated that Yellow Root (A. flava Merr.) was positively (being detected) containing secondary metabolite compounds such as alkaloid, saponin, terpenoid and flavonoid. Tannin indicated negative result (not detected). 


\section{$\Lambda$ Macrothink}

3. Chloroform extract produced the biggest preventive zone if compared to n-hexane, ethyl acetate, acetone, methanol, ethanol and water-based extracts.

\section{References}

Achmad, S. A. (1986). Chemistry of Organic Natural Products. Karnunika. Jakarta.

Barbour, E. K., M.A., Sharif, V. K., Sagherian, A. N., Habre, R. S., Talhouk, \& S. N., Talhouk. (2004). Screening of selected indigenous plants of Lebanon for antimicrobial activity. Journal of Ethnopharmacology, 93, 1-7. http://dx.doi.org/10.1016/j.jep.2004.02.027

Brock, T. D., \& Madigan, M. T. (1991). Biology of Microorganisms. Sixth edition. Mexico: Prentice Hall International.

Darusman, L., K. Sajuthi, D. Komar, \& Pamungkas, (1995). Extraction of bioactive components as a drug of shellfish. Marine sponges and algae in the waters Pari Island Thousand Islands. Bulletin Chemistry. Bogor: Faculty of Mathematics and Natural Sciences. Bogor Agricultural University.

Fardiaz, S., Suliantari, \& Dewanti, R. (1988). Antimicrobial Compounds. Bogor: Inter-University Center for Food and Nutrition, Bogor Agricultural University.

Gulluce, M., M. Sökmen, D., Daferera, G., Aqar, H., Ozkan, N. Kartal, M. Polissiou, A. Sokmen, F. Sahin, (2003). In Vitro Antibacterial, Antifungal, and Antioxidant Activities of the Essential Oil and Methanol Extracts of Herbal Parts and Callus Cultures of Satureja hortensis L. J. Agricultural and Food Chemistry,51,(14), 3958-3965.

Hadioetomo, R. S., (1983). Microbiology in Practice. Section of Microbiology, Faculty of Mathematics and Natural Sciences, Bogor Agricultural University.

Harborne, J. B., (1987). Phytochemical Methods Simplified Method Wizard Analyzing Plant. Padmawinata, K., translator. Second Edition. Bandung: ITB. Translation of: Phytochemical Methods.

Hendry, T. A. (1913). The Plants Alkaloid. J \& A Churchil. London.

Igbinosa, O. O., E. O., Igbinosa, \& O. A., Aiyegoro, (2009). Antimicrobial activity and phytochemical screening of stem bark extracts from Jatropha curcas (Linn)

Jaiarj, P., P. Khoohaswan, Y. Wongkrajang, P. Peungvicha, P. Suriyawong, M. L. S., Saraya, \& O. Ruangsomboon. (1999). Anticough and antimicrobial activities of Psidium guajava Linn. leaf extract. Journal of Ethnopharmacology, 67, 203-212. http://dx.doi.org/10.1016/S0378-8741(99)00022-7

Kähkönen, M. P., A. I., Hopia, H. J., Vuorela, J. P., Rauha, K. Pihlaja, T. S. Kujala, \& M. Heinonen, (1999). Antioxidant Activity of Plant Extracts Containing Phenolic Compounds. Journal Of Agricultural and Food Chemistry, 47(10), 3954-3962. http://dx.doi.org/10.1016/S0378-8741(99)00022-7

Karaman, I., F. Sahin, M. Gulluce, H. Ogutcus, M. Sengul, \& A. Adiguzel, (2003). 
Antimicrobial activity of aqueous and methanolextracts of Juniperus oxycedrus L. Journal Of Ethnopharmacology, 85, 231-235. http://dx.doi.org/10.1016/S0378-8741(03)00006-0

Kim, J., M. R., Marshall, \& C. Wei, (1995). Antibacterial activity of some essential oil components against five foodborne pathogens. Journal Agricultural And Food Chemistry, 43 (11), 2839-2845. http://dx.doi.org/10.1021/jf00059a013

Parekh, J., \& Chanda, S., (2007) . In vitro antibacterial activity of the crude methanol extract of Woodfordia fruticosa Kurz. flower (Lythraceae). Brazilian Journal of Microbiology, 38.

Parish, M. E., Davidson, P. M., (1989). Methods for testing the efficacy of food antimicrobials. Di dalam: IFT Food Microbiology Division, editor. Antimicrobial and Their Use in Foods. Proceeding of the Symposium at the Annual Meeting of the Institute of Food Technologist; New Orleans, LA., June 19-22,1988. Chicago: Publication Office, Institut of Food Technologist. Pages 149-155.

Pelczar, M. J., \& dan E. C. S., Chan. (1986). Dasar-dasar Mikrobiologi I. Alih Bahasa R.S. Hadioetomo, T., Imas, S.S., Tjitrosomo dan S.L., Angka. Universitas Indonesia. Jakarta. 441 hal.

Ponnusamy, S. W. E., Gnanaraj, J. M., Antonisamy, V. Selvakumar, J. Nelson, (2010). The effect of leaves extracts of Clitoria ternatea Linn against the fish pathogens. Asian Pacific $\begin{array}{llll}\text { Journal of } & \text { Tropical } & \text { Medicine, } & 3(9),\end{array}$ http://dx.doi.org/10.1016/S1995-7645(10)60173-3

Ra, K. S., H. J., Suh, S. H., Chung, \& J. Y., Son, (1998). Antioxidant Activity of Solvent Extract From Onion Skin. Korean Journal of Food Science and Technology, 29(3), 595-600.

Ringo, E, F Jutfelt, P Kanapathippillai, Y Bakken, K Sundell, J Glette, T M. Mayhew, R Myklebust, \& R E Olsen. (2004). Damaging effect of the fish pathogen Aeromonas salmonicida ssp. salmonicida on intestinal enterocytes of Atlantic salmon (Salmo salar L.). Cell and Tissue Research, 318(2), 305-311. http://dx.doi.org/10.1007/s00441-004-0934-2

Robinson, T. (1995). Ingredients Organic Compounds Plant High. Translated by Prof. Kosasih Padmawinata . ITB. Bandung

Sangi, M. M., R. J., Runtuwene, H. E. I., Simbala, \& V. M. A., Makang. (2008). Phytochemical Analysis of Plant Medicine in North Minahasa regency. Progress chemistry, 1, 47-53.

Siddhuraju, P. \& Becker, K., (2003). Antioxidant Properties of Various Solvent Extracts of Total Phenolic Constituents from Three Different Agroclimatic Origins of Drumstick Tree (Morin ga oleiferaLam.) Leaves. Journal of Agricultural and Food Chemistry, 51(8), 2144-2155. http://dx.doi.org/10.1021/jf020444+

Sokmen, A., M. Gulluce, H. A., Akpulat, D. Daferera, B. Tepe, M. Polissiou, M. Sokmen, \& F. Sahin, (2004). The in vitro antimicrobial and antioxidant activitiesof the essential oils and methanolextractsof endemic Thymus spathulifolius. Food Control, 15, 627-634. http://dx.doi.org/10.1016/j.foodcont.2003.10.005 
Sosa, R. A., M. G. G., Franco, A. C. Dávila, J. V. T., Munoz, \& G. V. N., Moorill. (2010). Extracts of Mexican Oregano (Lippia berlandieri Schauer) with Antioxidant and Antimicrobial Activity. Food and Bioprocess Technology, 3,(3), 434-440. http://dx.doi.org/10.1007/s11947-008-0085-7

Schlegel, H.G., \& Schmidt, K., (1994). General Microbiology. Tedja Baskara, translator. Yogyakarta: Gadjah Mada University Press. Translation of: Allgemeine Mikrobiologie.

Toranzo, A. E., J. L., Barja, R. R., Colwelland, \& F. M., Hetrick, (1983). Characterization of plasmids in bacterial fish pathogen. Infection and. Immunity, 39 (1), 184-192.

Yulita, (2002). The effectiveness of powdered leaves of guava (Psidium guajava L.), betel leaf (Piper betle L.) and bitter leaf (Andrographis paniculata (Burn F.) for prevention and treatment in African catfish fish (Clarias sp.) Infected with Aeromonas hydrophila.(Unpublished Magister Thesis). IPB. Bogor.

Zong, Z. L., Xiaoju, G. Yanyu, (2002). Aeromonas hydrophila infection: clinical aspects and therapeutic options. Medical Microbiology, 13(4), 151-162. http://dx.doi.org/10.1097/00013542-200210000-00002

\section{Copyright Disclaimer}

Copyright reserved by the author(s).

This article is an open-access article distributed under the terms and conditions of the Creative Commons Attribution license (http://creativecommons.org/licenses/by/3.0/). 